\title{
Combined chemo- and immunotherapy of tumors induced in mice by $b c r$-abl-transformed cells
}

\author{
EVA SOBOTKOVA, MARTINA DUSKOVA, RUTH TACHEZY, \\ MARTINA PETRACKOVA and VLADIMIR VONKA \\ Department of Experimental Virology, Institute of Hematology and Blood Transfusion, Prague, Czech Republic
}

Received October 22, 2008; Accepted December 4, 2008

DOI: 10.3892/or_00000286

\begin{abstract}
For our experiments we selected two oncogenic, bcr-abl-transformed mouse cell lines, viz. B210 and 12B1. Both cell types are capable of inducing leukemia-like disease in syngeneic BALB/c mice after intravenous inoculation. 12B1 cells can moreover form solid tumors after subcutaneous injection. Since immunotherapy would expectedly be most effective in animals in which the tumor mass had been reduced by other therapeutic means, we attempted to develop a combined therapeutic system for suppressing tumor growth. In the present study, mice inoculated with the aggressive 12B1 cells were treated with imatinib mesylate (IM), mouse interferon $\alpha$ (IFN $\alpha$ ) and cyclophosphamide (Cy) in combination with genetically modified tumor cells engineered to produce various cytokines. These cell vaccines had been derived from B210 cells. Therapy with IM or IFN $\alpha$ alone or cell immunotherapy alone resulted in partial suppression of tumor growth. Of the different therapeutic regimens tested, a combination of repeated doses of IM, IFN $\alpha$ and cell vaccines with one relatively high dose of Cy $(200 \mathrm{mg} / \mathrm{kg}$ ) was the most effective, resulting in tumor-free survival of a large portion of mice. The spleens, livers and bone marrows of the successfully treated animals were tested for the presence of $b c r-a b l$-positive cells by means of RTPCR technique. Results were negative, this suggesting that the animals had been cleared of residual disease.
\end{abstract}

\section{Introduction}

Chronic myeloid leukemia (CML) is a lethal disease of blood stem cells. In the pathogenesis of this disease, the key role is played by the $b c r-a b l$ fusion gene, which originates from a translocation between chromosomes 9 and 22. The product of the fusion gene exists in three forms, viz. p210

Correspondence to: Professor Vladimir Vonka, Institute of Hematology and Blood Transfusion, Department of Experimental Virology, U Nemocnice 1, 12820 Praha 2, Czech Republic E-mail: vladimir.vonka@uhkt.cz

Key words: chronic myeloid leukemia, mouse bcr-abl-transformed cells, cell vaccines, imatinib mesylate, cyclophosphamide, interferon $\alpha$ or $\mathrm{p} 230^{\mathrm{bcr}-a b l}$. Of these, $\mathrm{p} 210^{\mathrm{bcr}-\mathrm{abl}}$ is the most common. The $b c r-a b l$ fusion protein has a markedly increased activity of tyrosine-kinase (TyKi), which is coded for by the SH1 domain of the $a b l$ gene. It is generally accepted that this activity is responsible for both the cell transformation and the maintenance of the transformation state $(1,2)$.

Targeting the TyKi activity of $b c r-a b l$ appears to be a highly attractive therapeutic strategy (3). Imatinib mesylate (IM), one of the 2-phenylaminopyrimidine derivatives, is a direct inhibitor of the TyKi activity of the BCR-ABL fusion protein (4-6). IM competitively inhibits the interaction of these proteins with adenosine triphosphate (ATP) (7) which is necessary for TyKi activity. IM inhibits the growth of bcr-ablpositive cells both in vivo and in vitro (8-10) and is capable of inducing long-term remissions and prolonging the life of CML patients considerably (11-13). In the treatment of chronic phase CML, IM has provided much better hematological and cytogenetic responses than INF $\alpha$ (14), which until recently was widely used for CML treatment. Already the early studies in mouse model systems also proved a high efficacy of IM, viz. retardation of the growth of tumors induced by $b c r-a b l$ transformed cells $(4,9,15)$. In the past few years several mechanisms of resistance to IM have been recognized $(13,15-17)$. Furthermore, in spite of its high specificity and low toxicity, some dose-dependent side effects of IM have been reported $(12,18)$. Quite recently impairment of proliferation and function of $\mathrm{CD} 4{ }^{+} \mathrm{CD} 25^{+}$cells (19) and a strong, though transient anti-leukemia immune reaction (20) have been observed in IM-treated patients. On the basis of the experience with this drug, combination of IM with other antileukemic agents has been proposed and examined. Burchert et al (21) have reported that the concurrent or sequential combinatory therapy with IFN $\alpha$ and IM, taking advantage of their different effector mechanisms, has been more effective in the treatment of CML than any current monotherapy. Also our results (Sobotkova et al, unpublished data) indicated that a combination of IM with INF $\alpha$ was more effective in suppressing leukemia-like disease induced by the bcr-abl-transformed Ba-P210 (B210) cells developed by Daley and Baltimore (22) than its treatment with either of these substances alone (23). A combination of IM with INF $\alpha$ and other substances in vitro has resulted in additive or synergistic antiproliferative effects, with $b c r$-abl-positive cell lines having been used (24-26). For example, Kano et al (25) have shown some synergistic in vitro cytotoxic effects of IM 
and recombinant IFN $\alpha$ and an additive effect of 4-hydroperoxy-cyclophosphamide [the active form of cyclophosphamide (Cy)]. Because of the immunomodulatory activity of Cy (27-30) one could expect additional beneficial in vivo effects of this drug if used either alone or in combination with the above drugs and/or with experimental vaccines.

In the study reported below, the therapy of disease induced in mice by $b c r$-abl-transformed cells was attempted with IM, INF $\alpha$ and $\mathrm{Cy}$, applied either alone or in various combinations and in combination with vaccines based on another syngeneic $b c r$-abl-transformed cell line that had been engineered to produce either interleukin-2 (IL-2) or interleukin-12 (IL-12) or the granulocyte-monocyte colony-stimulating factor (GM-CSF). To be able to easily reveal possible synergistic effects, we employed suboptimal treatment regimens with IM and INF $\alpha$.

\section{Materials and methods}

Cell lines and media. Two BALB/c mouse cell lines transformed by the $b c r-a b l$ gene (b3a2) and expressing p210 ${ }^{\text {bcr-abl }}$ protein were used. 12B1 cells were obtained through the courtesy of E. Katsanis (University of Arizona, Tuscon, AZ, USA). They had been derived by transformation of primary bone marrow cells with a retrovirus-derived vector carrying the $b c r-a b l$ fusion gene (31). Ba-P210 (B210) cells were kindly provided by G.Q. Daley (Whitehead Institute of Biochemical Research, Cambridge, MA, USA). They had been derived from interleukin 3 (IL-3)-dependent Ba/F3 cells (22). Their transduction by the $b c r-a b l$ gene carried by a retroviral vector had made them IL-3-independent. We described the basic in vitro and in vivo characteristics of these two cell lines in more detail elsewhere $(10,32)$. In brief, both express approximately the same amounts of the $\mathrm{p} 210^{\mathrm{bcr}-\mathrm{abl}}$ protein but differ in MHC class I expression (it is down-regulated in B210 cells) and in oncogenic potential. While B210 induce leukemia-like disease at doses exceeding $5 \times 10^{4}$ cells only after intravenous (i.v.) inoculation, 12B1 induce leukemia at doses $<10^{2}$ cells after i.v. inoculation and, in addition, induce solid tumors after subcutaneous (s.c.) inoculation of doses equal to or $>10^{3}$ cells. These tumors exhibit a high metastatic activity to spleen, liver and bone marrow. Both cell lines are highly susceptible to IM in vitro. After i.v. inoculation of $5 \times 10^{5} \mathrm{~B} 210$ cells, the animals develop leukemia in the course of the third week. After s.c. inoculation of $5.10^{3} 12 \mathrm{~B} 1$ cells, animals form rapidly growing solid tumors that appear after 12-14-day incubation. Bcr-abl-negative HL-60 cells were used as a negative control in PCR (see below). All cell lines were passaged in RPMI-1640 medium (Sigma-Aldrich Corp., St. Louis, MO, USA) supplemented with 10\% FCS (PAA Labs., Linz, Austria), $2 \mathrm{mmol} / \mathrm{l}$ glutamine and antibiotics. In the case of $12 \mathrm{~B} 1$ cells, the medium was furthermore enriched with 1 $\mathrm{mmol} / \mathrm{l}$ sodium pyruvate and $50 \mu \mathrm{mol} / 12$-mercaptoethanol.

Cell vaccines. After repeated passages of B210 cells in the presence of increasing concentrations of 5-bromo-2'deoxyuridine (BUDR), a thymidine-kinase-less (TK') subline was isolated. These cells, designated B210TK $/ \mathrm{cl}-2$, grew well in the presence of $100 \mu \mathrm{g}$ BUDR, but did not grow in medium supplemented with hypoxanthine, aminopterin and thymidine
(HAT media Supplement, Invitrogen, Carlsbad, CA, USA) and were oncogenic for mice after i.v. inoculation. After transfection with bicistronic plasmids carrying genes for herpes simplex virus TK (HSV TK) and for various cytokines, genetically modified cell lines were isolated in HAT media. The construction of these plasmids was described previously (33). In addition to HSV TK, the gene-modified cells expressed IL-2 (B210/IL-2, IL-2 production $46.5 \mathrm{ng} / 10^{6} / 24 \mathrm{~h}$ ), IL-12 (B210/IL-12, IL-12 production $130 \mathrm{ng} / 10^{6 / 24} \mathrm{~h}$ ) or GM-CSF (B210/GM-CSF, GM-CSF production $40 \mathrm{ng} / 10^{6} / 24 \mathrm{~h}$ ). In vitro, all three cell lines were highly sensitive to ganciclovir, this confirming HSV TK production, and were non-oncogenic after i.v. inoculation (Petrackova et al, unpublished data).

Animals used and tumor induction. Seven- to 8-week old $\mathrm{BALB} / \mathrm{c}$ female mice were used in all experiments. They had been obtained from Charles Rivers, Germany. The mice were inoculated s.c. with $5 \times 10^{3} 12 \mathrm{~B} 1$ cells in $0.2 \mathrm{ml}$ PBS. In therapeutic experiments, $10^{6}$ B210/IL-2, B210/IL-12 or B210/GM-CSF cells in $0.2 \mathrm{ml}$ PBS were repeatedly injected intraperitoneally (i.p.) (see the Results section). The animals were inspected for tumor development at least twice a week and tumor size was measured with a caliper. Animals carrying tumors exceeding $20 \mathrm{~mm}$ in their longest diameter were humanely sacrificed. All animal studies were done in accordance with the Guidelines for Animal Experimentation valid in the Czech Republic.

Reagents. Imatinib mesylate (IM, STI571, Glivec) was a generous gift from Novartis (Basel, Switzerland). It was dissolved in distilled water $(1 \mathrm{mg} / \mathrm{ml})$, sterilized by filtration through a Millipore filter, distributed into vials and kept at $-20^{\circ} \mathrm{C}$ until use. It was inoculated i.p., one dose $(50 \mathrm{mg} / \mathrm{kg})$ per day, five times a week for one or two weeks, starting on day 3 or 10 after the s.c. inoculation of 12B 1 cells. Cyclophosphamide (Cy) (Farmos, Finland) was given in a single i.p. dose, $200 \mathrm{mg} / \mathrm{kg}$, on day 3 after inoculation of 12B1 cells. Recombinant mouse interferon $\alpha$ (INF $\alpha)$ (Calbiochem, Merk Biosciences, Darmstadt, Germany) was administered starting on day 3 or day 10, one dose (1000 IU) per day, five times a week, for one or two weeks.

PCR used for detection of bcr-abl-positive cells in animal tissues.

Sampling. Livers and spleens were taken from a portion of the mice surviving the treatment without tumor development and from some tumor-bearing animals. The tissues were immediately frozen in liquid nitrogen and stored at $-70^{\circ} \mathrm{C}$ until examination. Bone marrow was also sampled from some animals. It was obtained by irrigating tight bone with $1 \mathrm{ml}$ of sterile PBS. Cells were counted with a haemocytometer. RNA extraction (see below) was done immediately after collection of cells. Similarly treated organs from diseased animals served as positive controls.

RNA extraction. Prior to RNA extraction, the samples (250 mg of thawed liver or spleen tissue, or $4-10 \times 10^{6}$ bone marrow cells) were homogenized with a TH 220 hand-held homogenizer with disposable tips (Cole Parmer, IL, USA) in 
$1 \mathrm{ml}$ RTL (a guanidium thiocyanate containing buffer provided by the producer) and supplemented with B-merkapto-ethanol provided in the Qiagen RNeasy mini kit (Qiagen, Hilden, Germany). Total RNA was isolated by means of the Qiagen RNeasy mini kit with On-Column DNase digestion using an RNase-free DNase set, in accordance with the manufacturer's protocol (Qiagen). The concentration of RNA was measured with a UV spectrometer (BioMate 3, Thermo Fisher Scientific, Inc., USA) and the quality of RNA was checked on agarose gel. Prior to reverse transcription, any possibly remaining DNA was removed by treating $2 \mu \mathrm{g}$ amounts of the RNA extracts with $1 \mathrm{U} / \mu \mathrm{g}$ of DNase I (Roche Diagnostics $\mathrm{GmbH}$, Mannheim, Germany) at $37^{\circ} \mathrm{C}$ for $30 \mathrm{~min}$ in a total volume of $20 \mu \mathrm{l}$. The enzyme was subsequently inactivated by incubation at $65^{\circ} \mathrm{C}$ for $10 \mathrm{~min}$. RNA samples were stored at $-70^{\circ} \mathrm{C}$ until their examination.

Reverse transcription. DNase-treated RNA (2 $\mu \mathrm{g})$ was reverse transcribed using an oligo $(\mathrm{dT})_{18}$ primer, $50 \mathrm{U}$ MMLV reverse transcriptase (Promega, Madison, WI, USA) and $20 \mathrm{U}$ Rnasin (Promega) in a total volume of $20 \mu 1$. After an initial denaturation of RNA at $70^{\circ} \mathrm{C}$ for $10 \mathrm{~min}$, the master mix was placed on ice and the sample was incubated at $37^{\circ} \mathrm{C}$ for $60 \mathrm{~min}$.

$P C R$. The quality of cDNA was assessed by PCR with primers specific for the house-keeping $B$-actin gene (forward 5'CCACTGGGACGACATGGAGAAGAT3'; reverse 5'CAT GGCTGGGGTGTTGAAGGTC3'), which amplify the 166-bplong fragment. The expression of the bcr-abl gene was monitored by means of nested PCR with a set of external primers that amplify the 327-bp-long fragment (forward 5'TTCAGAAGCTTCTCCCTG3'; reverse 5'CTCCACTGGC CACAAAAT3') and a set of internal primers that amplify the 245-bp-long fragment from the b3a2 spliced gene (forward 5'GTGAAACTCCAGACTGTC3'; reverse 5'CAACGAAAA GGTTGGGGT3'). Fifty microlitres of the first reaction mixture contained $5 \mathrm{pM} / \mu 1$ of each primer, $1.5 \mathrm{mM} \mathrm{MgCl}_{2}$, $2 \mathrm{mM}$ dNTPs, $0.5 \mathrm{U}$ of Taq polymerase (Fermentas, Vilnius, Lithuania) and 1X PCR buffer with $\left(\mathrm{NH}_{4}\right)_{2} \mathrm{SO}_{4}$ (Fermentas). For the second PCR, $1 \mu 1$ of 10 -fold diluted PCR product of the first reaction was used. Initial denaturation at $94^{\circ} \mathrm{C}$ for 5 min was followed by 35 cycles, each consisting of $1 \mathrm{~min}$ at $94^{\circ} \mathrm{C}, 90 \mathrm{sec}$ at $57^{\circ} \mathrm{C}, 90 \mathrm{sec}$ at $72^{\circ} \mathrm{C}$ and a final extension at $72^{\circ} \mathrm{C}$ for $7 \mathrm{~min}$. The reaction mixture and cycling conditions for the second PCR were the same as for the first one. As a positive control, RNA extracted from B210 cells, and as a negative control, RNA extracted from HL60 cells, was used.

Statistical analysis. Tumor development was analyzed in $2 \times 2$ contingency tables by the two-tailed Fisher's exact test. For analysis of the growth curves of the tumors, the two-way analysis of variance was used. Calculations were done using the Prism Software Version 3.0 (Graph-Pad Software, San Diego, CA). A difference between groups was considered significant at $\mathrm{p}<0.05$.

\section{Results}

Effects of Cy, IM and IFNa on the growth of 12B1-induced tumors. Animals inoculated s.c. in the right back with a
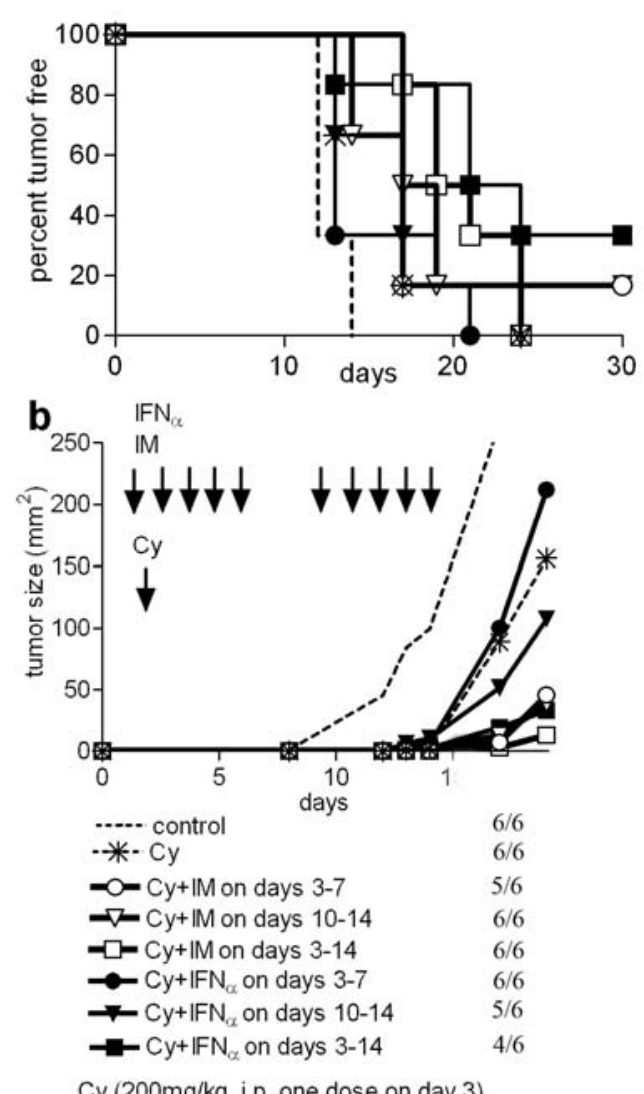

Cy $(200 \mathrm{mg} / \mathrm{kg}$, i.p.,one dose on day 3$)$

IM or IFN $\mathrm{I}_{\alpha}$ for one or two weeks

Figure 1. Effect of Cy, IM and IFNa on the growth of tumors induced by 12B1 cells. (a) tumor development, (b) tumor growth. The measurement of tumor size was terminated when it reached or just exceeded $20 \mathrm{~mm}$ in its longest diameter. Arrows indicate the days after 12B1 cell inoculation when the drugs were administered.

$5 \times 10^{3} 12 \mathrm{~B} 1$ cells were treated with Cy $(200 \mathrm{mg} / \mathrm{kg})$ alone or in combination with either IM (50 mg/kg/day) or INFa (1000 IU/ day). Cy was administered in a single dose on day 3 , while the other substances were given once a day for 5 or 10 days starting on day 3 or day 10, after the cell administration. The results of a representative experiment are shown in Fig. 1. It is evident from Fig. 1a that although nearly all mice developed tumors before the end of the observation period, $\mathrm{Cy}$ given alone or in combination with either IM or INF $\alpha$ induced a considerable delay in their appearance. This delay was statistically significant $(\mathrm{p}<0.02)$ in all the combinations tested except that in which INF $\alpha$ was given on days 3-7. Fig. 1b shows that tumors grew at a much slower rate in mice treated with the drug combinations, more so in those treated with $\mathrm{Cy}$ in combination with IM $(\mathrm{p}<0.001)$ than with INF $\alpha$ (nonsignificant) for the early or late treatment and $p<0.01$ for the early+late treatment. Furthermore, treatment with the Cy plus IM combination was significantly more efficient than treatment with $\mathrm{Cy}$ alone $(\mathrm{p}<0.01)$. Similar results were obtained in repeated experiments.

Effect of cell vaccines producing IL-2, IL-12 or GM-CSF on the growth of 12B1-induced tumors. Animals inoculated s.c. with $5 \times 10^{3} 12 \mathrm{~B} 1$ cells on day 0 were repeatedly i.p. injected 
Table I. Presence of $b c r$-abl-positive cells in treated and untreated mice inoculated with $12 \mathrm{~B} 1$ cells.

\begin{tabular}{|c|c|c|c|c|c|c|}
\hline 12B1 cells & Therapy & Tumor present & Day of sampling ${ }^{\mathrm{a}}$ & Bone marrow & Spleen & Liver \\
\hline \multirow[t]{2}{*}{ i.v. } & - & + & 12 & $2 / 2^{b}$ & $2 / 2$ & $2 / 2$ \\
\hline & - & + & 18 & $\mathrm{NT}^{\mathrm{c}}$ & $2 / 2$ & $2 / 2$ \\
\hline s.c. & - & + & 15 & NT & $3 / 3$ & $3 / 3$ \\
\hline s.c. & $\mathrm{Cy}+\mathrm{IFN} \alpha+\mathrm{B} 210 / \mathrm{IL}-2$ & - & 124 & $0 / 4$ & $0 / 4$ & $0 / 4$ \\
\hline s.c. & Cy+IM+B210/IL-2 & - & 123 & $0 / 2$ & $0 / 2$ & $0 / 2$ \\
\hline s.c. & Cy+B210/IL-12 & - & 123 & $0 / 1$ & $0 / 1$ & $0 / 1$ \\
\hline s.c. & $\mathrm{Cy}+\mathrm{IFN} \alpha+\mathrm{B} 210 / \mathrm{GM}-\mathrm{CSF}$ & - & 123 & $0 / 1$ & $0 / 1$ & $0 / 1$ \\
\hline
\end{tabular}

${ }^{a}$ Number of positive animals/number tested in RT-PCR. ${ }^{b}$ After 12B1 cell inoculation. ${ }^{\mathrm{c}}$ Not tested.

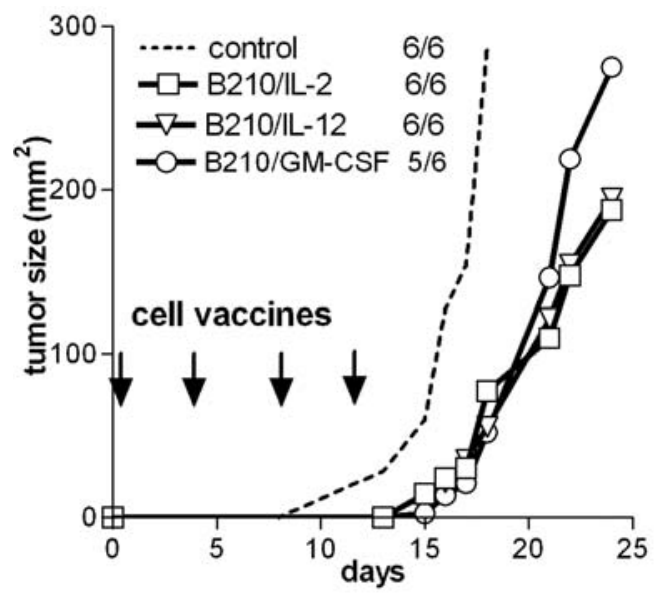

Figure 2. Effect of live B210 cell-based vaccines expressing different cytokines on the growth of tumors induced by 12B1 cells. Arrows indicate the days after 12B1 inoculation when the vaccines were administered.

with B210-cell vaccines producing IL-2, IL-12 or GM-CSF ( $10^{6}$ cells per dose). The vaccines were given on days $0,3,7$ and 10. It is evident from Fig. 2 that the therapy did not prevent tumor development, but it significantly postponed the appearance of tumors as compared with control animals ( $p<0.01$ in the case of all three vaccines). The tumors grew at a somewhat slower rate in animals injected with either the IL-2 or IL-12-producing cells than in those injected with GMCSF-producing cells; however, 1 of the 6 animals in the latter group survived without tumor formation.

Effect of cell-vaccine therapy combined with Cy, IM and IFNa administration on the growth of tumors induced by $12 \mathrm{Bl}$ cells. Having obtained some basic information as to the effectiveness of the drugs tested and evidence that the cell-based vaccines can produce some, though a limited effect on 12B1 tumor formation, we decided to combine the two approaches. In the ensuing experiment the cell vaccines were administered in the same way as previously. A single dose of Cy was i.p. injected on day 3 , either alone or in combination with the repeated administration of IM and/or IFN $\alpha$. The latter substances were injected on days 3 to 7 and 10 to 14. The amount of each drug per dose was the same as in the preceding experiments. Results are shown in Fig. 3.
It can be seen that the administration of $\mathrm{Cy}$ alone resulted in a significant postponement of tumor appearance $(\mathrm{p}<0.05)$, but did not prevent tumor formation in any of the animals. A similar effect was observed in animals treated with mixtures of $\mathrm{Cy}$ and either IM or INF $\alpha$ or both. Animals which received $\mathrm{Cy}$ and any one of the three vaccines also responded similarly. However, when the combined Cy+cell-vaccine treatment was supplemented with either IM or INF $\alpha$ in the case of the B210/IL-2 vaccine (Fig. 3a and b), or with INFa in the case of the B210/IL-12 vaccine (Fig. 3c and d), tumors appeared later and grew slower $(\mathrm{p}<0.001)$ than in the non-vaccine-treated animals. Most importantly, some animals did not develop tumors at all. This was most frequent in those treated with the B210/IL-2 vaccine. Two of the 6 mice which, in addition to the Cy+cell vaccine, also received IM, and 4 of the 6 animals which received INF $\alpha$ in addition to the $\mathrm{Cy}+\mathrm{vaccine}$, remained tumor-free until the end of the observation period. The protective effects of the B210/IL-2 and B210/IL-12 vaccines administered in the above combinations were significantly higher than in the groups treated with $\mathrm{Cy}$ alone $(\mathrm{p}<0.01$, $<0.001$ and $<0.02$, respectively). On the other hand, no beneficial effects of the B210/GM-CSF vaccine were apparent (Fig. 3e and $\mathrm{f}$ ).

The vaccine treated mice surviving tumor-free for four months were tested for the presence of $b c r$-abl transcripts in cells obtained at autopsy from their livers, spleens and bone marrows. The results presented in Table I testify to the absence of leukemic cells in all of the surviving animals. On the other hand, both control animals with 12B1-induced tumors possessed $b c r$-abl-positive cells in the organs tested, this indicating a high propensity for metastizing of these tumors.

\section{Discussion}

The recently enhanced interest in the combination of chemoand immunotherapy of CML is paralleled by an increased interest in suitable animal models, in which specific immune responses to $b c r-a b l$-positive cells can be studied much more easily than in human patients. In the study reported herein, we used 12B1 mouse cells, which carry the bcr-abl gene and express the $\mathrm{p} 210^{\mathrm{bcr}-a b l}$ protein and the drugs most widely used for the treatment of human CML, i.e. IM (now) and INFa (until recently). The treatment regimen with these substances was intentionally suboptimal, because we expected that under these 

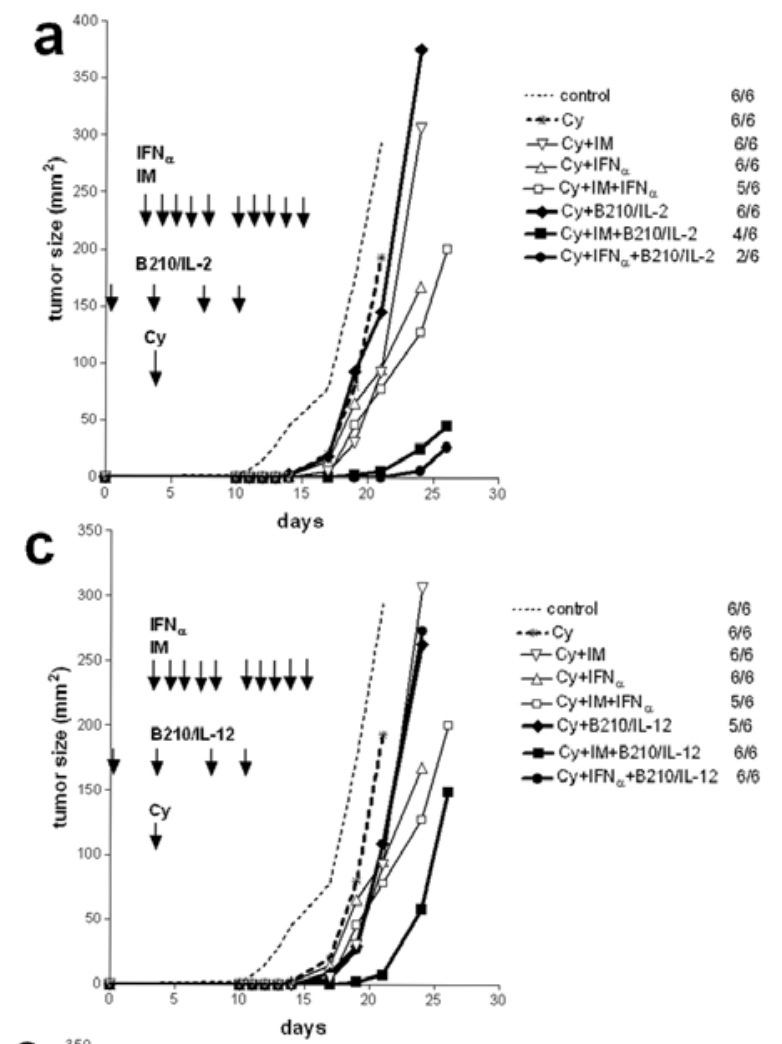

b
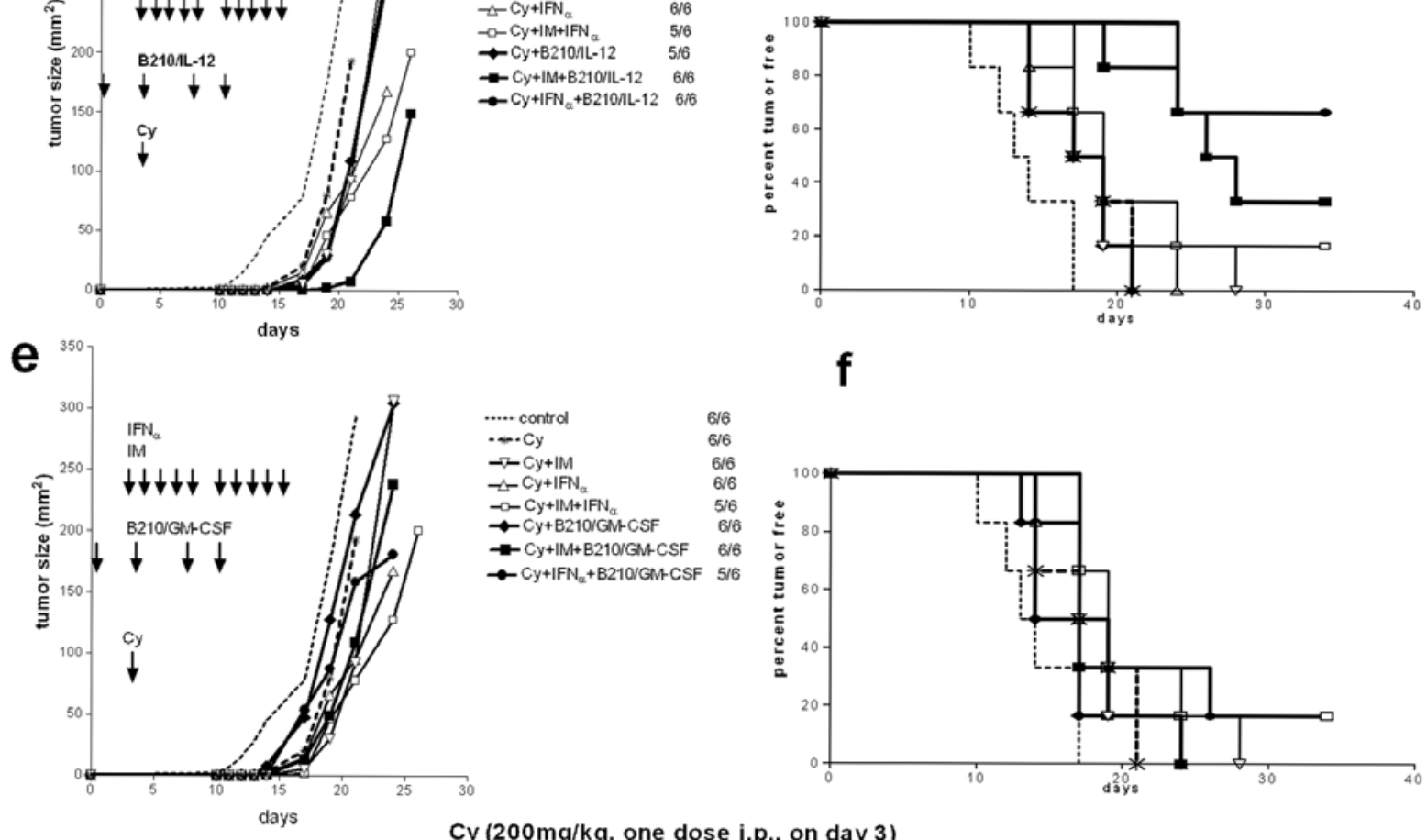

f

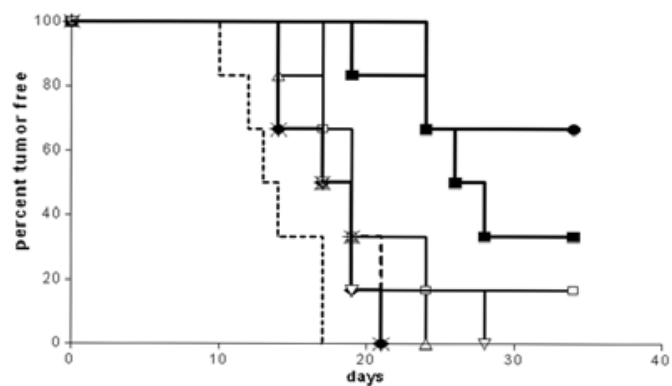

d

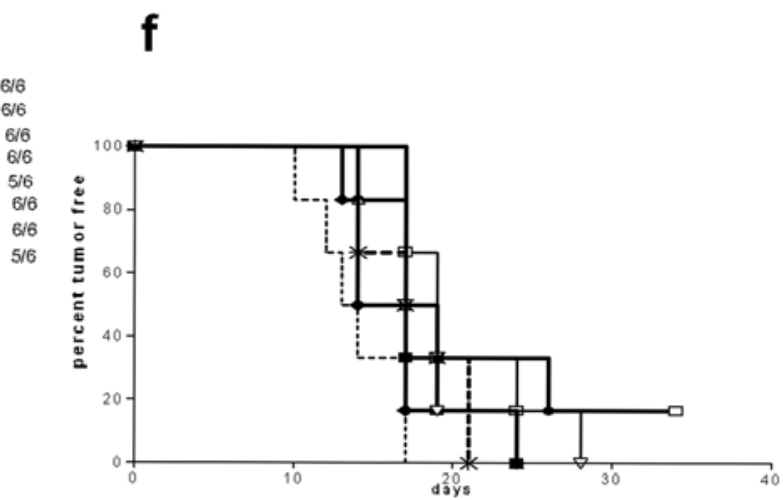

Cy $(200 \mathrm{mg} / \mathrm{kg}$, one dose i.p., on day 3$)$

IM (1 $\times 50 \mathrm{mg} / \mathrm{kg} /$ day, i.p., for two weeks starting on day 3$)$

IFN $_{\alpha}(1000$ IU/day, i.p.,for two weeks starting on day 3)

cell vaccines $\left(10^{6}\right.$ cells per dose, i.p., on days $0,3,7$ and 10$)$

Figure 3. Effect of therapy with Cy, IM and/or IFN $\alpha$ combined with live B210 cell-based vaccine administration on the growth of tumors induced by 12B1 cells. (a and b) Treatment with B210/IL-2 vaccine, (c and d) treatment with B210/IL-12 vaccine and (e and f) treatment with B210/GM-CSF vaccine. Arrows indicate time after 12B1 cell inoculation when the drugs and the vaccines were administered.

conditions any possibly synergistic effects would be more evident. These drugs were supplemented with Cy and with specific vaccines based on heterologous but syngeneic B210 cells, which also express the $\mathrm{p} 210^{\mathrm{bcr}-\mathrm{abl}}$ protein and, in addition, several immunostimulatory factors known from many previous studies to enhance anti-tumor reactions.

In agreement with our previous results obtained with B210 cells (Sobotkova $e t$ al, unpublished data) and with results obtained in patients with CML (21,34-36), combinations of two or more of the above-mentioned drugs increased their effectiveness in the treatment of tumors induced by 12B1 cells. The mutual interactions of these substances are not quite clear at this writing. While the mechanism of action of IM is understood well, this is not so with the other two agents used.
It is believed that the beneficial effects of INF $\alpha$ in the treatment of CML are mediated by both its immunomodulatory and antiproliferative effects (37-39). Similar effects can be expected in the case of $\mathrm{Cy}$. Although this substance has been extensively used as a cytostatic drug in cancer treatment, recent evidence has made it clear that it suppresses regularory $\mathrm{T}$ cells $(28,30,40,41)$ and may have some other beneficial immunomodulatory effects (42-44). In those experiments lower doses of $\mathrm{Cy}$ (28) than in our present undertaking have been used. Thus it is likely that the antiproliferative effect of the substance played a major role in our system. This conjecture of ours is further supported by our earlier observation that a reduction of the Cy dose markedly decreased its effects (unpublished data). 
The vaccines used in our present study were prepared with B210 cells transformed by the bcr-abl fusion gene and expressing the $\mathrm{p} 210^{\mathrm{bcr}-\mathrm{abl}}$ protein. Gene-modified cells expressing IL-2, IL-12 or GM-CSF were employed. Since they were free of oncogenic potential (Petrackova et al, unpublished data), they were used for therapeutic vaccination as live cells. In the therapeutic regimen chosen, none of the vaccines was capable of completely suppressing tumor development. However, all three delayed tumor formation significantly. Hoping that the concurrent administration of the chemo- and immunotherapy would result in a synergistic effect, we combined the two therapeutic modes. The combination was indeed more effective than the drug therapy alone. The effects were most conspicuous with the B210/IL-2 vaccine and weakest with the B210/GM-CSF vaccine. Some of the animals treated with the vaccine-drug combinations survived without developing tumors. The livers, spleens and bone marrows of these animals were checked by RT-PCR for the presence of $b c r$-abl-transcripts. The results were negative, which indicated that these animals were free of $b c r-a b l$-positive cells and could thus be considered free of residual disease.

Presumably, the different 'therapeutic' activities of the vaccines were a consequence of the biological activities inherent in the cytokines tested and they seem to be in line with the experience of other investigators as well as with our earlier observations in another system (45). Still, it is possible that also the amount of the cytokine produced played a role. Since live cells were used for the vaccination in our experiments, they continued to replicate in vivo for some time, with the replication rate, though limited, most likely varying between the cell lines tested and thus producing varying amounts of the immunizing antigens as well as of the cytokines. Experiments are under way in which cell vaccines derived from clones differing markedly in the production of GM-CSF are being tested.

At this writing, it is not understood which tumor-cell antigens are involved in establishing immunity to the highly aggressive 12B1 cells. Although we originally speculated that the new epitope carried by the fusion zone of the $\mathrm{p} 210^{\mathrm{bcr}-\mathrm{abl}}$ protein might mainly be involved, and in fact quite convincing evidence obtained in another laboratory (46-49) strongly indicated that this was the case, the results we obtained with a variety of genetic vaccines based on the fusion zone have not yet confirmed this (unpublished data). On the other hand, we have obtained evidence that other regions of the $\mathrm{p} 210^{\mathrm{bcr}-\mathrm{abl}}$ protein are able to induce protection against 12B1 cells (unpublished data). Furthermore, other antigens present in leukemic cells might also be involved. It has been reported that WT1 and proteinase 3 (Pr-3) are overexpressed in human leukemic cells and that it is possible to induce a beneficial immune reactivity in patients or experimental animals by peptide-based or other types of vaccines (50-53). Our attempts to demonstrate the presence of either WT1 or Pr-3 by using monoclonal antibodies against their mouse analogues have failed (unpublished data). However, it is conceivable that other proteins involved in the $\mathrm{p} 210^{\mathrm{bcr}-\mathrm{abl}}$ activities or in the transformation procedure itself are overexpressed in either cell line and act as immunogens. Experiments aiming to identify at least some of the proteins involved are underway.
To summarize, combination of chemotherapy and immunotherapy with vaccines based on gene-modified cells expressing IL-2 or IL-12 prevented development of tumors in a significant portion of mice inoculated with the highly aggressive p210 bcr-abl -positive $12 \mathrm{~B} 1$ cells.

\section{Acknowledgements}

The research study was supported by grant No. NR/9075-3 of the Internal Granting Agency, Ministry of Health, Czech Republic. The technical assistance of Dana Lesna and Marketa Sirova is highly appreciated.

\section{References}

1. Daley GQ, Van Etten RA and Baltimore D: Induction of chronic myelogenous leukemia in mice by the $\mathrm{P} 210^{\mathrm{bcr} / a b l}$ gene of the Philadelphia chromosome. Science 247: 824-830, 1990.

2. Kelliher MA, McLaughlin J, Witte ON and Rosenberg N: Induction of a chronic myelogenous leukemia-like syndrome in mice with v-abl and BCR/ABL. Proc Natl Acad Sci USA 87: 6649-6653, 1990

3. Wong S and Witte ON: The BCR-ABL story: bench to bedside and back. Annu Rev Immunol 22: 247-306, 2004.

4. Buchdunger E, Zimmermann J, Mett H, Meyer T, Müller M, Druker BJ and Lydon NB: Inhibition of the Abl protein-tyrosine kinase in vitro and in vivo by a 2-phenylaminopyrimidine derivative. Cancer Res 56: 100-104, 1996.

5. Druker BJ, Tamura S, Buchdunger E, et al: Effects of a selective inhibitor of the Abl tyrosine kinase on the growth of Bcr-Abl positive cells. Nat Med 2: 561-566, 1996

6. Gambacorti-Passerini C, le Coutre P, Mologni L, et al: Inhibition of the ABL kinase activity blocks the proliferation of $\mathrm{BCR} / \mathrm{ABL}^{+}$leukemic cells and induces apoptosis. Blood Cells Mol Dis 23: 380-394, 1997.

7. Schindler T, Bornmann W, Pellicena P, Miller WT, Clarkson B and Kuriyan J: Structural mechanism for STI-571 inhibition of abelson tyrosine kinase. Science 289: 1938-1942, 2000.

8. Deininger MW, Goldman JM, Lydon N and Melo JV: The tyrosine kinase inhibitor CGP57148B selectively inhibits the growth of BCR-ABL-positive cells. Blood 90: 3691-3698, 1997.

9. le Coutre P, Mologni L, Cleris L, et al: In vivo eradication of human BCR/ABL-positive leukemia cells with an ABL kinase inhibitor. J Natl Cancer Inst 91: 163-168, 1999.

10. Sobotkova E, Ludvikova V, Petrackova M, et al: Characteristic of two mouse bcr-abl-transformed cell lines: I. General properties of the cells. Folia Biol (Praha) 51: 12-18, 2005.

11. Frame D: New strategies in controlling drug resistence. J Manag Care Pharm 13: 13-17, 2007.

12. Fausel C: Targeted chronic myeloid leukemia therapy: seeking a cure. Suppl J Manag Care Pharm 13: S8-S12, 2007.

13. Moen MD, McKeage K, Plosker GL and Siddiqui MA: Imatinib: a review of its use in chronic myeloid leukaemia. Drugs 67: 299-320, 2007.

14. Druker BJ, O'Brien SG, Cortes J and Radich J: Chronic myelogenous leukemia. Hematology (Am Soc Hematol Educ Program), pp111-135, 2002.

15. Daley GQ: Towards combination target-directed chemotherapy for chronic myeloid leukemia: role of farnesyl transferase inhibitors. Semin Hematol 40: 11-14, 2003.

16. Buchdunger E: Bcr-Abl inhibition as molecular therapy approach in chronic myeloid leukemia. Med Klin (Munich) 97: 2-6, 2002.

17. Nimmanapalli $\mathrm{R}$ and Bhalla $\mathrm{K}$ : Mechanisms of resistance to imatinib mesylate in Bcr-Abl-positive leukemias. Curr Opin Oncol 14: 616-620, 2002.

18. Bartolovic K, Balabanov S, Hartmann U, et al: Inhibitory effect of imatinib on normal progenitor cells in vitro. Blood 103: 523-529, 2004.

19. Chen J, Schmitt A, Giannopoulos K, Chen B, et al: Imatinib impairs the proliferation and function of $\mathrm{CD} 4{ }^{+} \mathrm{CD} 25^{+}$regulatory $\mathrm{T}$ cells in a dose-dependent manner. Int J Oncol 31: 1133-1139, 2007.

20. Chen CI, Maecker HT and Lee PP: Development and dynamics of robust T-cell responses to CML under imatinib treatment. Blood 111: 5342-5349, 2008. 
21. Burchert A, Wölfl S, Schmidt M, et al: Interferon-alpha, but not the ABL-kinase inhibitor imatinib (STI571), induces expression of myeloblastin and a specific T-cell response in chronic myeloid leukemia. Blood 101: 259-264, 2003.

22. Daley GQ and Baltimore D: Transformation of an interleukin 3dependent hematopoietic cell line by the chronic myelogenous leukemia-specific P210 ${ }^{\mathrm{bcr} / a b l}$ protein. Proc Natl Acad Sci USA 85: 9312-9316, 1988.

23. Deng M and Daley GQ: Expression of interferon consensus sequence binding protein induces potent immunity against BCR/ABL-induced leukaemia. Blood 97: 3491-3497, 2001.

24. Thiesing JT, Ohno-Jones S, Kolibaba KS and Druker BJ: Efficacy of STI571, an abl tyrosine kinase inhibitor, in conjunction with other antileukemic agents against bcr-ablpositive cells. Blood 96: 3195-3199, 2000.

25. Kano Y, Akutsu M, Tsunoda S, Mano H, Sato Y, Honma Y and Furukawa Y: In vitro cytotoxic effects of a tyrosine kinase inhibitor STI571 in combination with commonly used antileukemic agents. Blood 97: 1999-2007, 2001.

26. Marley SB, Davidson RJ, Goldman JM and Gordon MY: Effects of combinations of therapeutic agents on the proliferation of progenitor cells in chronic myeloid leukaemia. Br J Haematol 116: 162-165, 2002

27. Bass KK and Mastrangelo MJ: Immunopotentiation with low-dose cyclophosphamide in the active specific immunotherapy of cancer Cancer Immunol Immunother 47: 1-12, 1998.

28. Motoyoshi Y, Kaminoda K, Saitoh O, et al: Different mechanisms for anti-tumor effects of low- and high-dose cyclophosphamide. Oncol Rep 16: 141-146, 2006.

29. Salem ML, Kadima AN, El-Naggar SA, Rubinstein MP, Chen Y, Gillanders WE and Cole DJ: Defining the ability of cyclophosphamide preconditioning to enhance the antigen-specific $\mathrm{CD} 8^{+} \mathrm{T}$-cell response to peptide vaccination: creation of a beneficial host microenvironment involving type I IFNs and myeloid cells. J Immunother 30: 40-53, 2007.

30. Taieb J, Chaput N, Schartz N, et al: Chemoimmunotherapy of tumors: cyclophosphamide synergizes with exosome based vaccines. J Immunol 176: 2722-2729, 2006.

31. McLaughlin J, Chianese E and Witte ON: In vitro transformation of immature hematopoietic cells by the P210 BCR/ABL oncogene product of the Philadelphia chromosome. Proc Natl Acad Sci USA 84: 6558-6562, 1987.

32. Jelínek F, Sobotková E and Vonka V: Characteristic of two mouse bcr-abl-transformed cell lines. II. Pathological lesion induced in mice. Folia Biol (Praha) 51: 93-102, 2005

33. Ludvíková V, Hamsíková E, Sobotková E, Lucansky V, Smahel $\mathrm{M}$ and Vonka V: Use of polyclonal rabbit antibodies for detection of the bcr-abl fusion zone in cells transfected with experimental bcr-abl DNA vaccines. Int J Oncol 27: 265-274, 2005.

34. O'Brien S, Giles F, Talpaz M, et al: Results of triple therapy with interferon-alpha, cytarabine, and homoharringtonine, and the impact of adding imatinib to the treatment sequence in patients with Philadelphia chromosome-positive chronic myelogenous leukemia in early chronic phase. Cancer 98: 888-893, 2003.

35. Kantarjian HM, O'Brien S, Cortes J, et al: Imatinib mesylate therapy improves survival in patients with newly diagnosed Philadelphia chromosome-positive chronic myelogenous leukemia in the chronic phase: comparison with historic data. Cancer 98: 2636-2642, 2003.

36. Druker BJ: Imatinib alone and in combination for chronic myeloid leukemia. Semin Hematol 40: 50-58, 2003.
37. Paquette RL, Hsu N, Said J, et al: Interferon-alpha induces dendritic cell differentiation of CML mononuclear cells in vitro and in vivo. Leukemia 16: 1484-1489, 2002.

38. Burchert A and Neubauer A: Interferon alpha and T-cell responses in chronic myeloid leukemia. Leuk Lymphoma 46: 167-175, 2005.

39. Bracci L, Proietti E and Belardelli F: IFN-alpha and novel strategies of combination therapy for cancer. Ann NY Acad Sci 1112: 256-268, 2007

40. Ghiringhelli $\mathrm{F}$, Larmonier N, Schmitt E, et al: $\mathrm{CD}^{+} \mathrm{CD} 25^{+}$ regulatory $\mathrm{T}$ cells suppress tumor immunity but are sensitive to cyclophosphamide which allows immunotherapy of established tumors to be curative. Eur J Immunol 34: 36-44, 2004.

41. Ghiringhelli F, Menard C, Puig PE, et al: Metronomic cyclophosphamide regimen selectively depletes $\mathrm{CD} 4{ }^{+} \mathrm{CD} 25^{+}$ regulatory $\mathrm{T}$ cells and restores $\mathrm{T}$ and $\mathrm{NK}$ effector functions in end stage cancer patients. Cancer Immunol Immunother 56: 641-648, 2007.

42. Mitchell MS: Immunotherapy as part of combinations for the treatment of cancer. Int Immunopharmacol 3: 1051-1059, 2003.

43. Bracci L, Moschella F, Sestili PI, et al: Cyclophosphamide enhances the antitumor efficacy of adoptively transferred immune cells through the induction of cytokine expression, B-cell and T-cell homeostatic proliferation, and specific tumor infiltration. Clin Cancer Res 13: 644-653, 2007.

44. Nowak AK, Lake RA and Robinson BW: Combined chemoimmunotherapy of solid tumours: improving vaccines? Adv Drug Deliv Rev 58: 975-990, 2006.

45. Sobotková E, Dusková M, Smahel M, Holán V, Janousková O and Vonka V: Chemotherapy and immunotherapy of tumours induced by gene-modified HPV16-transformed cells. Oncol Rep 12: 877-883, 2004

46. He L, Feng H, Raymond A, et al: Dendritic-cell-peptide immunization provides immunoprotection against bcr-ablpositive leukemia in mice. Cancer Immunol Immunother 50: 31-40, 2001

47. Zeng Y, Graner MW, Feng H, Li G and Katsanis E: Imatinib mesylate effectively combines with chaperone-rich cell lysateloaded dendritic cells to treat bcr-abl+ murine leukemia. Int J Cancer 110: 251-259, 2004.

48. Zeng Y, Graner MW, Thompson S, Marron M and Katsanis E: Induction of BCR-ABL-specific immunity following vaccination with chaperone-rich cell lysates derived from $\mathrm{BCR}-\mathrm{ABL}^{+}$tumor cells. Blood 105: 2016-2022, 2005.

49. Kislin KL, Marron MT, Li G, Graner MW and Katsanis E: Chaperone-rich cell lysate embedded with BCR-ABL peptide demonstrates enhanced anti-tumor activity against a murine BCR-ABL positive leukemia. FASEB J 21: 2173-2184, 2007

50. Gaiger A, Reese V, Disis ML and Cheever MA: Immunity to WT1 in the animal model and in patients with acute myeloid leukemia. Blood 96: 1480-1489, 2000.

51. Ohminami H, Yasukawa M and Fujita S: HLA class I-restricted lysis of leukemia cells by a CD8(+) cytotoxic T-lymphocyte clone specific for WT1 peptide. Blood 95: 286-293, 2000.

52. Oka Y, Tsuboi A, Elisseeva OA, Udaka K and Sugiyama H: WT1 as a novel target antigen for cancer immunotherapy. Curr Cancer Drug Targets 2: 45-54, 2002.

53. Scheibenbogen C, Letsch A, Thiel E, et al: CD8 T-cell responses to Wilms tumor gene product WT1 and proteinase 3 in patients with acute myeloid leukemia. Blood 100: 2132-2137, 2002. 